\title{
De betekenis van producent Jean Van Raemdonck voor de Vlaamse film
}

Meer dan een halve eeuw lang gold de Belgische producent Jean Van Raemdonck (I922-2010) als de verpersoonlijking van de productiemaatschappij Art et Cinéma, vaak beter bekend onder de Nederlandstalige naam Kunst en Kino. Na tientallen kunstdocumentaires geproduceerd te hebben, begon Van Raemdonck zich tegen het einde van de jaren zestig toe te leggen op de productie van fictieprojecten, waarmee Kunst en Kino al gauw tot een van de belangrijkste Belgische film- en televisieproductiehuizen uitgroeide. Hoewel Van Raemdonck gedurende zijn hele carrière ook bij Franstalige projecten betrokken bleef, waren het vooral zijn Nederlandstalige lange speelfilms - vaak in coproductie met een Nederlands productiehuis - waarmee hij de meeste bekendheid verwierf. Met succesvolle verfilmingen van het Vlaams literair erfgoed zoals MiRa (I97I), PALLIETER (I975), DE LEEUW VAN VLAANDEREN (I984) en HET GEZIN VAN PAEMEL (I987) bepaalde hij in aanzienlijke mate het aanzien van de Vlaamse film van de jaren zeventig en tachtig. Van Raemdonck wordt algemeen geprezen om het professionalisme dat hij binnenbracht in de Belgische audiovisuele sector in het algemeen, en in de Vlaamse filmsector in het bijzonder. ${ }^{\mathrm{I}}$

Ondanks zijn belang voor het audiovisuele landschap van de Lage Landen in de tweede helft van de twintigste eeuw, ging er tot nog toe erg weinig (academische zowel als nietacademische) aandacht uit naar Van Raemdoncks rol als producent. Dit hangt samen met de meer algemene veronachtzaming van Europese producenten binnen film- en mediastudies. Terwijl bij de bestudering van Hollywood een sterke onderzoekstraditie bestaat die zich toespitst op studio's en producenten, ${ }^{2}$ zien we dat de sterkere regisseursgerichte filmtraditie in Europa zich ook doorzet in de academische aandacht. Hierdoor waren het primaat van de regisseur en de artificiële opdeling tussen de artistieke en zakelijke aspecten van een film lange tijd dominant. Sinds de jaren I980 wordt echter steeds meer benadrukt dat de rol van de producent ook buiten Hollywood meer inhoudt dan de complexe taken die te maken hebben met het verkrijgen van financiële middelen en het overtuigen van investeerders. ${ }^{3}$ Het hieraan verbonden strategische handelen komt ook van pas bij de diverse andere organisatorische taken van de producent tijdens de periode waarin een film tot stand komt en wordt uitgebracht. De beslissingen die producenten tijdens dit proces nemen, hebben vaak een verregaande invloed: van de keuze van een te verfilmen onderwerp en het selecteren van cast en crew tot meer rechtstreekse creatieve beslissingen. Bij grotere producties worden de producenttaken vaak 
opgesplitst en is er bijvoorbeeld sprake van executive producers (die zorgdragen voor onder andere de financiering), line producers (die het dagelijkse werk van cast en crew overziet) en associate producers (die de line producers assisteren en bijvoorbeeld voor de contacten met laboratoria of technisch personeel zorgen).

Binnen de context van de Belgische film van de jaren zeventig en tachtig werden deze functies echter meestal grotendeels uitgeoefend door een en dezelfde persoon: de producent. Dit gold zelfs voor de - naar Belgische normen - groots opgezette en prestigieuze producties van Van Raemdonck, wat deels samenhangt met de mate waarin hij controle uitoefende over zijn producties. Deze bijdrage biedt in eerste instantie een algemeen inzicht in de ontwikkeling van de productieactiviteiten van Van Raemdonck en in het spanningsveld tussen de ideologische, culturele en commerciële imperatieven waarin hij steeds opereerde. Vervolgens gaat de aandacht uit naar Van Raemdoncks professionele aanpak en welke strategische keuzes hij maakte om binnen het financieel moeilijke Belgische filmproductieklimaat een zekere continuiteit aan filmproducties te verwezenlijken. Hierbij gaat het om de relatie tussen Van Raemdonck en het Vlaamse filmproductiebeleid, dat steeds instond voor een substantieel deel van de financiering van zijn belangrijkste producties; de focus van deze bijdrage ligt op deze Vlaamse lange speelfilms uit de jaren zeventig en tachtig. Op een ruimer vlak draagt dit artikel

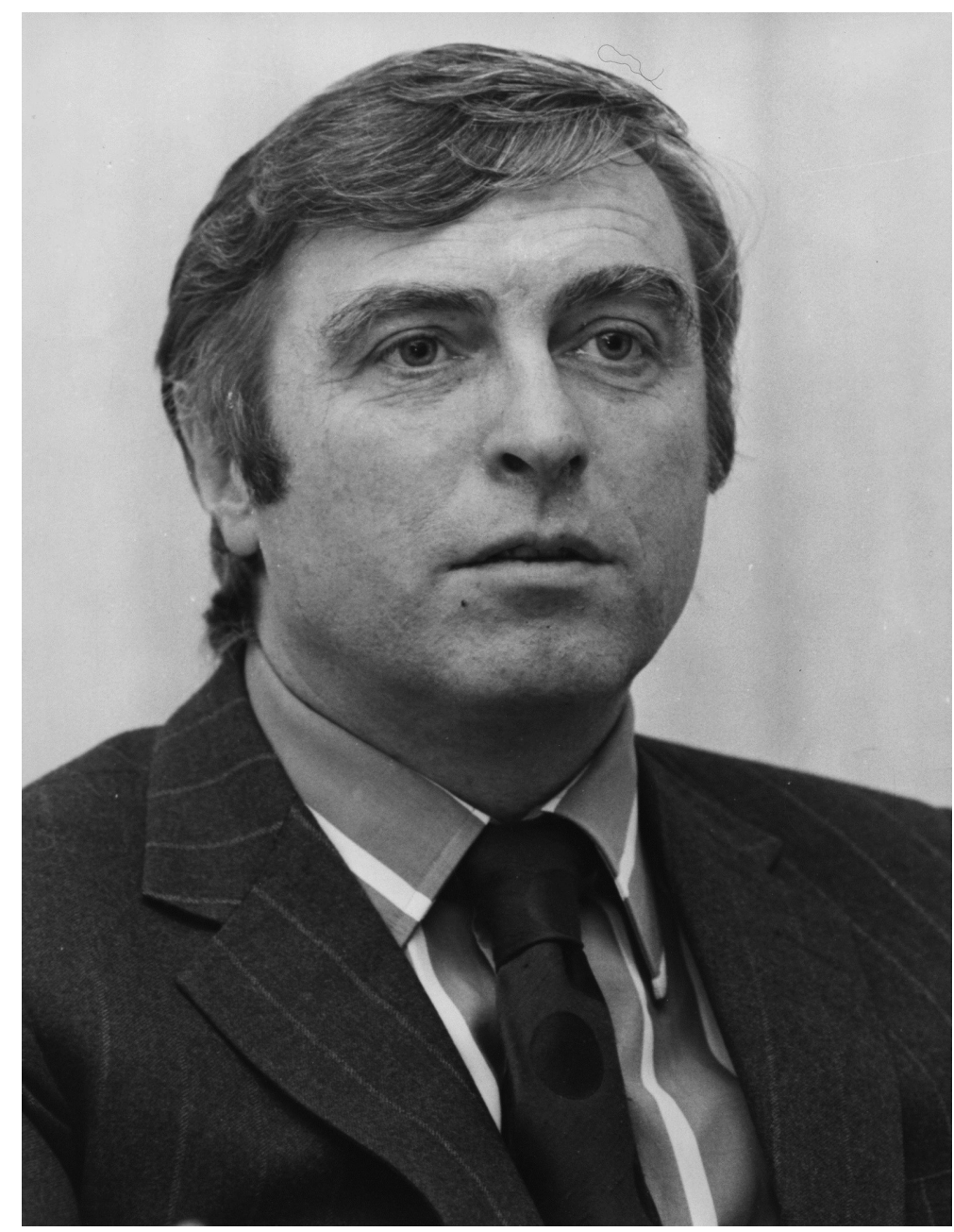

Jean Van Raemdonck (1922-2010)

Bron: Koninklijk Belgisch Filmarchief, fotograaf J. Pol Payen 
bij aan een beter begrip van de functie film- en televisieproducent binnen de zich ontwikkelende Vlaamse en ruimere Belgische audiovisuele context doorheen de tweede helft van de twintigste eeuw. Gezien de vele samenwerkingen met Nederland, maar ook met Frankrijk en andere Europese landen, overschrijdt de reikwijdte van deze bijdrage bovendien het louter Belgische kader.

Dit onderzoek is gebaseerd op origineel archiefmateriaal, verzamelde persartikels en interviews met betrokkenen. Helaas werd het archief van Kunst en Kino nagenoeg volledig vernietigd toen productiemaatschappij Eyeworks de rechten van de Kunst- en-Kino-catalogus opkocht. Deze beperking werd voor zover als mogelijk gecompenseerd door intensief op andere bronnen terug te plooien. Het archief van het filmdepartement van de Vlaamse overheid, ondergebracht in het Rijksarchief te Beveren, was hierbij van het grootste belang. Het Documentatiecentrum voor de Cinematografische Pers (DOCIP) en het Koninklijk Filmarchief (beide te Brussel) boden de bronnen uit de pers. Voor de interviews werden zowel regisseurs, producenten als beleidsactoren geselecteerd die door hun professionele activiteiten konden getuigen over (werken met) Van Raemdonck. ${ }^{4}$ Door een geïntegreerde analyse van de verschillende bronnen wenst deze studie een beter inzicht te verschaffen over de betekenis van de producent Van Raemdonck binnen de Belgische audiovisuele sector.

\section{Van kunstdocumentaires naar fictieproductie}

Jean Van Raemdonck werd geboren in 1922 binnen een welgestelde Franstalige familie die in Gent woonde. Reeds in zijn jeugdjaren raakte hij gefascineerd door het medium film; hij bezocht dikwijls de filmvoorstellingen van Le Club de l'Écran en later L'Écran du Séminaire des Arts (de voorlopers van het filmmuseum, vandaag Cinematek) in het Paleis voor Schone Kunsten te Brussel. ${ }^{5}$ Deze interesse leidde onder andere tot een stage bij de productiepoot van de filmmaatschappij Pathé in Parijs. Van Raemdonck zette vervolgens zijn eerste stappen in de Belgische filmsector als hoofd van het in I948 opgerichte Cinéma Inter-Entreprises. Volgens de statuten van de firma bestond het doel erin wetenschappelijke, technologische en educatieve films te produceren en te distribueren. Door de gelijkaardige doelstellingen fuseerde Cinéma Inter-Entreprises al gauw met het van overheidswege ingerichte Institut National de Cinéma Scientifique. ${ }^{6}$ Intussen had Van Raemdoncks schoonbroer, de veelzijdige kunstenaar en criticus Paul Haesaerts, samen met de befaamde Belgische cineast Henri Storck de veel geroemde kunstdocumentaire RUBENS (I948) gerealiseerd.7 Na deze positieve ervaring richtte Haesaerts de productiemaatschappij Art et Cinéma op om zijn kunstdocumentaire-activiteiten verder te ontplooien. Kort na de oprichting van Art et Cinéma stelde Haesaerts zijn schoonbroer Van Raemdonck aan als hoofd van de afdeling productie. ${ }^{8}$ In die functie produceerde Van Raemdonck in de jaren vijftig en zestig meer dan dertig films over kunstonderwerpen, waaronder de bekende visite À PICASso (I949).

Haesaerts regisseerde bijna al deze kunstdocumentaires die zowel op televisie als op gespecialiseerde vertoningscircuits werden vertoond. Voor de financiering deed Van Raemdonck een beroep op Belgische financiers, zowel Frans- als Nederlandstalige. Dit resulteerde in kunstdocumentaires in het Frans, Nederlands en soms in beide talen. Naast incidentele overheidstoelagen of commissies verstrekt door publieke instituten zoals het Paleis voor 
Schone Kunsten en (veelal) de Belgische publieke televisie, investeerden ook particuliere kunstliefhebbers met een industriële of andere financieel interessante achtergrond in de kunstprojecten van Van Raemdonck. Deze periode gold zo ongeveer als Van Raemdoncks leerschool, waarbij hij zijn strategisch talent om projecten te pitchen en diverse financieringsbronnen aan te boren kon ontplooien, een talent dat hij bij zijn latere fictieproducties ten volle zou inzetten. Tegelijk droeg Van Raemdonck met deze activiteiten bij aan de uitbouw van de internationaal gerenommeerde 'Belgische traditie' in het genre van de kunstdocumentaire. ${ }^{9}$

Gedurende de tweede helft van de jaren zestig bouwde Haesaerts zijn filmactiviteiten binnen Art et Cinéma af. In deze jaren begon Van Raemdonck, die een sterke interesse voor fictie koesterde, steeds meer op het voorplan te treden. Nog voor Haesaerts' overlijden in I974 - Van Raemdonck werd toen officieel algemeen bestuurder - was Van Raemdonck al de personificatie van het bedrijf, die. De bedrijfsactiviteiten had hij toen al definitief in de richting van fictieproductie gestuurd. De groeiende vraag naar producties vanuit televisie en de invoering van structurele filmsubsidiesystemen in België gedurende de jaren zestig zorgden voor groeiende (financiële) mogelijkheden. In de begin- en eindjaren van Art et Cinéma zagen een aantal Franstalige film- en televisieproducties het licht. Van Raemdoncks eerste fictieproject was de internationale, populaire jeugdtelevisieserie Les Galapiats (I969, Pierre Gaspard-Huit), over de avonturen van een groepje tieners op een zomerkamp in de Belgische Ardennen. ${ }^{\circ}{ }^{\circ}$ De vroege kleurenserie werd gefinancierd door een consortium van francofone televisieomroepen, met de Belgische Franstalige publieke omroep RTв als drijvende kracht. Ondanks het succes in diverse landen zou Van Raemdonck pas in I987 opnieuw Franstalige televisieproductie ter hand nemen als initiator van de transnationale televisieserie L'HEURE SIMENON, gebaseerd op verschillende werken van de bekende Franstalige Belgische schrijver Georges Simenon. Vanaf de jaren negentig tot aan het begin van de twintigste eeuw - aan het einde van zijn carrière - produceerde Van Raemdonck nog diverse low-profile Franstalige televisiefilms, zoals MON VOISIN DU DESSUS (2003, Laurence Katrian). ${ }^{\text {II }}$

Rond dezelfde tijd als LES GALAPIATS produceerde Van Raemdonck Jean-Pierre Berckmans' kortfilm SI TU SAVAIS (I970). Berckmans regisseerde vervolgens de enige Franstalige lange speelfilms van Art et Cinéma (telkens in coproductie met Frankrijk), de erotisch geïnspireerde literatuuradaptaties LA CHAMbre ROUGe (I972) en ISABELLE DEVANT LE DÉSIR (I975). Midden jaren tachtig ging Van Raemdonck nog eenmaal verder op dit erotische spoor, ditmaal iets explicieter met THE SECRETS OF LOVE (I986, Harry Kümel), een compilatie van drie korte kostuumfilms gebaseerd op verhalen van de klassieke Franse schrijvers Marguerite de Navarre, Nicolas-Edme Rétif en Guy de Maupassant. Hoewel THE SECRETS OF LOVE een coproductie was met Gerrit Visschers Nederlandse productiebedrijf CinéVista, werd de film gesynchroniseerd in het Engels en vervolgens in het Frans, aangezien de drie korte films geïntegreerd werden in de Franse erotische Série Rose televisiereeks. Het zwaartepunt van Van Raemdoncks productieactiviteiten ligt echter bij de Nederlandstalige lange speelfilms uit de jaren zeventig en tachtig.

Van Raemdoncks eerste lange speelfilm was MIRA, een mijlpaal in de Vlaamse en Nederlandse filmgeschiedenis. Het initiatief voor deze film kwam van de BRT (de Nederlandstalige divisie van de Belgische Radio- en Televisieomroep), die de honderdste geboortedag van 
de Vlaamse schrijver Stijn Streuvels wou vieren met een filmadaptatie van DE TELEURGANG VAN DEN WATERHOEK (I927). ${ }^{\text {I2 }}$ Van Raemdonck raakte bij dit project betrokken via de scenarioschrijver Hugo Claus, die kort voordien nog met Art et Cinéma had samengewerkt voor Paul Haesaerts' kunstdocumentaire BREUGEL (I969). Claus wist ook zijn Nederlandse vriend en toen reeds gevestigd cineast Fons Rademakers te engageren om de film, met een prijskaartje van I7 miljoen Belgische francs, te regisseren en te coproduceren. MIRA gaat over een traditionele plattelandsgemeenschap aan het begin van de twintigste eeuw, die zich verzet tegen de opkomende moderniteit in de vorm van de constructie van een brug. Tegelijk refereert de film aan de hippiecultuur die in de tijd van de productie van de film floreerde, door de focus op de liberale en vrije houding van het titelpersonage, gespeeld door de Nederlandse Willeke Van Ammelrooy. ${ }^{\mathrm{I3}}$ De naaktscènes met haar zorgden er mee voor dat de film uitgroeide tot een enorm populair succes, zowel in Nederland (430.265 bioscoopbezoekers) als in België, waar de film met 642.400 bioscoopbezoekers tot eind jaren tachtig de binnenlandse bioscoophitlijsten aanvoerde. Bovendien werd de film geselecteerd voor de officiële competitie van het filmfestival van Cannes, wat het artistieke aanzien van de film verhoogde.

Dit succes luidde de 'pastorale filmtrend' in Kunst en Kino's productieactiviteiten in. DE LOTELING (I973, Roland Verhavert), PALLIETER (I975, Roland Verhavert), DE VLASCHAARD (I983, Jan Gruyaert), DE LEEUW VAN VlaANDEREN (I984, Hugo Claus) en HET GEZIN VAN PAEMEL (I987, Paul Cammermans) tonen aan dat Van Raemdonck het populaire succes van bepaalde elementen uit de 'MIRA formule' verder wilde exploiteren. ${ }^{\mathrm{I}}{ }^{4}$ Dit hield in dat een werk uit de Vlaamse heimatliteratuur werd geadapteerd, wat resulteerde in historische films over de plattelandsbevolking in de negentiende of aan het begin van de twintigste eeuw (met uitzondering van DE LEEUW VAN VLAANDEREN, die opgezet was als een middeleeuwse ridderfilm), waarbij vrouwelijk naakt nooit ontbrak. Het hedendaagse, progressieve element uit MIRA werd echter in veel mindere mate overgenomen. Aangezien de pastorale Kunst en Kino-films tot de duurste en meest prestigieuze Vlaamse producties behoorden, en vaak het meeste publiek naar de bioscopen wisten te lokken, bepaalden ze voor een aanzienlijk deel het aanzien van de Vlaamse film in de jaren zeventig en tachtig. ${ }^{15}$ Hoewel deze films geprezen werden omwille van bepaalde artistieke kwaliteiten, zoals hun picturale beeldvoering, werden ze ook bekritiseerd om hun romantisch, nostalgisch en conservatief karakter. Gezien de overeenkomsten met de Britse 'heritagefilms' en de Duitstalige 'heimatfilms', is het dan ook niet verwonderlijk dat de pastorale Kunst en Kino-producties vaak geïnterpreteerd worden in termen van Vlaamse natievorming. ${ }^{16}$ Van Raemdonck zelf, de drijvende kracht achter deze producties, bleek echter in de eerste plaats het commerciële succes van deze films te zien.

Vier van de zes pastorale films waren coproducties met Nederland. Voor MIRA gebeurde dit via regisseur het productiehuis van Fons Rademakers. Voor DE LEEUW VAN VLAANDEREN, die naast een film ook een televisieserie behelsde, kwam de coproductie tot stand via een samenwerking tussen de BRT en de Nederlandse omroep KRO (Katholieke Radio Omroep), zoals wel vaker voor kostbare televisieproducties gebeurde. Voor PALLIETER en DE VLASSCHAARD vond Van Raemdonck een geschikte coproductiepartner in de figuur van Gerrit Visscher, die eerst producent was voor het Nederlandse Cinécentrum en vanaf I982 zijn eigen productiehuis CinéVista had. De samenwerkingen volgden het reciprociteits- of wederkerigheidsprincipe; in 
ruil voor Vissschers participatie in PALLIETER en DE VLASSCHAARD engageerde Van Raemdonck zich als coproducent voor de Nederlandse literaire adaptaties DOKTER VLIMMEN (I978, Guido Pieters) en WILDSCHut (I985, Bobby Eerhart).

De meest terugkerende naam bij de Kunst en Kino-productie was die van Hugo Claus, de belangrijkste literaire figuur uit Vlaanderen in de tweede helft van de twintigste eeuw. Van Raemdonck werkte graag samen met Claus, omdat hij hem zag als een kwaliteitswaarborg, maar ook omdat Claus' naam extra publieke aandacht garandeerde, zowel in Vlaanderen als in Nederland. Claus schreef of werkte mee aan het scenario van de pastorale (landelijke, idyllische) films MIRA, PALLIETER, HET GEZIN VAN PAEMEL en DE LEEUW VAN VLAANDEREN. Voor deze laatste productie nam hij ook de regie op zich, net als voor de adaptatie van zijn eigen theaterstuk VRIJDAG (I980), waarvoor Visscher opnieuw als coproducent gold. Daarnaast leverde hij ook het scenario voor twee van Kunst en Kino's meest prestigieuze televisieseries: RUbens, SCHILder En DiplomaAt (I977, Roland Verhavert), naar het leven van de barokschilder Peter Paul Rubens, en Het VerdRIET VAN België (I995, Claude Goretta), naar Claus' eigen magnum opus uit I983. HET VERDRIET VAN BELGIË zou Van Raemdoncks laatste grote productie vormen. Ondanks een aantal prestigieuze en vaak vrij populaire producties slaagde Van Raemdonck er reeds in de jaren tachtig niet meer in het niveau te handhaven van de hoogtijdagen in de jaren zeventig. Vanaf I987, toen de pastorale film HET GEZIN VAN PAEMEL niet het grote publiek van weleer wist te bereiken, realiseerde Van Raemdonck enkel nog televisieproducties, meestal in coproductie met Belgische, Nederlandse of Franse televisiemaatschappijen. Desalniettemin bleef hij broeden op diverse projecten voor een lange speelfilm en was hij bijvoorbeeld een van de grondleggers van ScEUR SOURIRE (Stijn Coninx), die in 2009 in de bioscopen uitkwam, een jaar voor Jean van Raemdonck op 88-jarige leeftijd overleed.

\section{Creatieve inbreng}

Bij dit bondige overzicht van de belangrijkste Kunst en Kino-producties valt op dat zo goed als alle fictieproducties hun oorsprong vonden in het literaire (en/of breder culturele) erfgoed, meestal van Vlaanderen, maar ook van de Franstalige Belgische of de Franse traditie. Voor dit Leitmotiv bestonden twee motivaties. Allereerst kwam Van Raemdonck uit een milieu van hoge cultuur en was een kunstliefhebber die geloofde dat de kwaliteit en reputatie van een literair werk de kwaliteit van de cinematografische adaptatie ervan ten goede zou komen. Maar Van Raemdonck was ook zeer geïnteresseerd in de commerciële waarde van culturele producten. Dit vertaalde zich in een voorkeur voor niet enkel respectabele, maar ook breed bekende en succesvolle literaire werken als uitgangspunt voor zijn producties. Deze voorkeur voor een combinatie van een sterke culturele waarde van een werk en de commerciële troeven van een reeds bekende, pre-sold titel was bijvoorbeeld duidelijk bij de televisiebewerking van Claus' rOman HET VERDRIET VAN BELGIË die onmiddellijk als een meesterwerk onthaald werd en al vlug een bestseller bleek te zijn. ${ }^{\text {I7 }}$ Vaak was de commerciële aantrekkingskracht van een literair werk doorslaggevend voor Van Raemdoncks productiekeuzes. Dit werd sprekend geillustreerd door PALLIETER. Regisseur Roland Verhavert herinnert zich hoe na het publiekssucces van DE LOTELING Van Raemdonck aan hem vroeg: 'Wat is nu het meest populaire boek uit de Vlaamse 
literatuur? Ik zei: dat is PAllieter. Goed, dan verfilmen we PAllieter, zei hij. ${ }^{\text {I8 }}$ Tegelijk benadrukt Verhavert dat ondanks Van Raemdoncks sterk publieksgerichte attitude, hij nooit louter commercieel geïnspireerde films van welk allooi ook zou produceren, maar steeds een zekere culturele respectabiliteit van zijn producties eiste.

Van Raemdonck hield er een duidelijke visie op na en trachtte dan ook zo veel mogelijk de controle over de diverse aspecten van zijn producties te houden. Dit vertaalde zich in een strikte

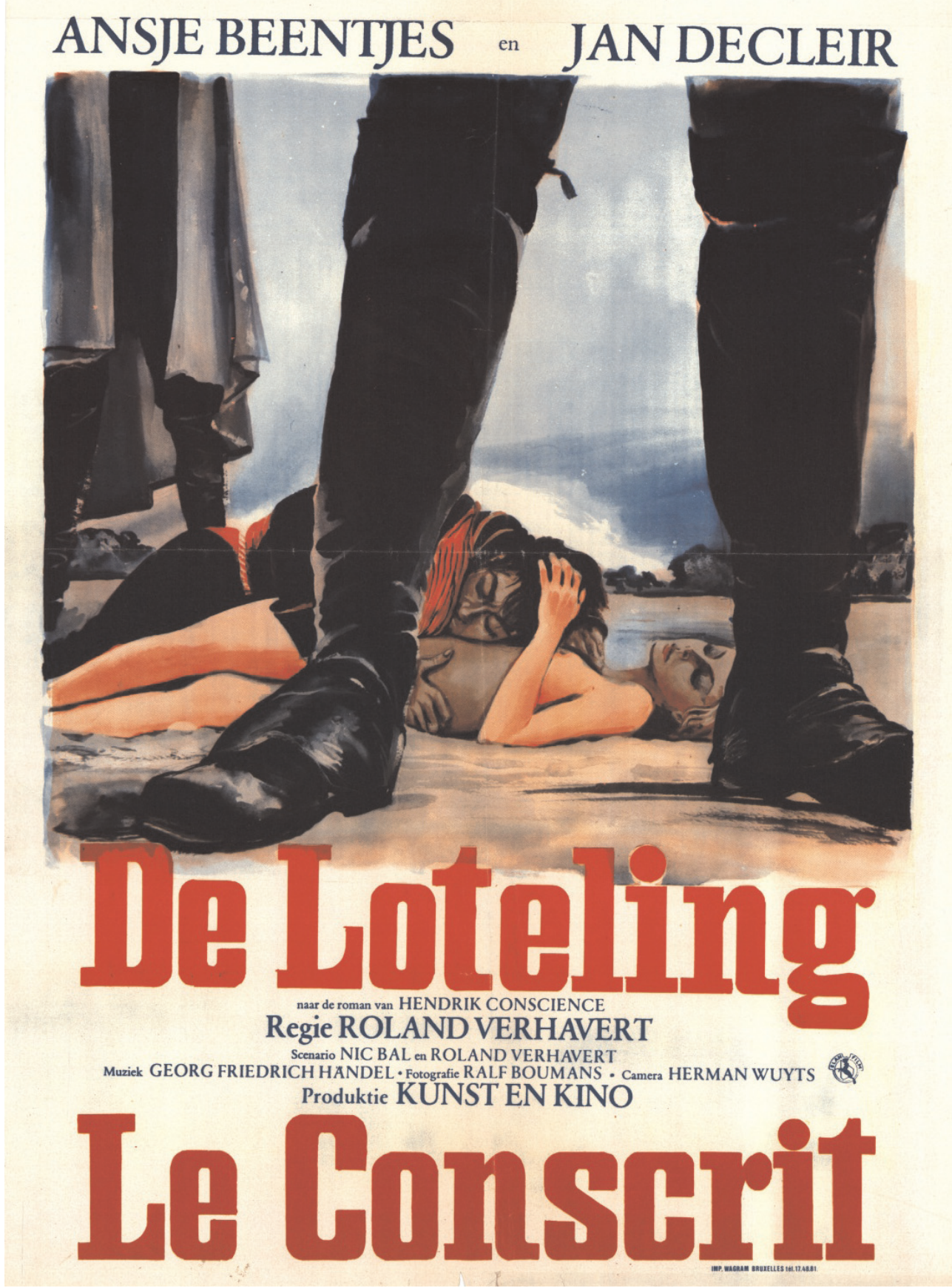

Filmaffiche DE LOTELING

Bron: Koninklijk Belgisch Filmarchief 
productiehiërarchie waarbij hijzelf de touwtjes stevig in handen had. Ondanks het feit dat Kunst en Kino in de jaren zeventig en tachtig uitgroeide tot de meest vooraanstaande en professionele productiemaatschappij in Vlaanderen, bleef het bedrijf steeds gelijkenissen vertonen met een eenpersoonszaak, wat correspondeerde met Van Raemdoncks reputatie als eenling. Zijn verregaande persoonlijke betrokkenheid bij zowat alle Kunst en Kino-producties liet zich ook voelen in een vrij autoritaire relatie met zijn medewerkers. ${ }^{19}$ Die roept uiteraard vragen op wie de creatieve autoriteit over de eindproducten was. ${ }^{20}$ Deze kwestie is des te interessanter als het gaat om Kunst en Kino's pastorale films, die door Mosley omschreven worden als 'respectable auteurist adaptations'. ${ }^{21}$ Deze films werden tot nog toe inderdaad meestal vanuit een regisseursperspectief benaderd. Gerrit Visscher herinnert zich hoe dit destijds 'ook de tijdsgeest [was]. Het creatieve van de regisseur moest een rol spelen, en dat wat de producent deed, was het zakelijke, een heel ander verhaal. Terwijl de werkelijkheid een andere was! ${ }^{22}$

Zo kwam Van Raemdonck meestal zelf met het filmonderwerp op de proppen. Het is in die context dat Sojcher hem als een producent à l'américaine bestempelt, ${ }^{23}$ daarmee doelend op het feit dat Van Raemdonck in de regel verder ook besliste over de regisseur, de scenarist, de acteurs, de cameralui, de monteur en andere sleutelfuncties. Dit was vrij uitzonderlijk voor de Belgische filmproductiecontext, waarbinnen de regisseur vaak de spil was en dikwijls zelfs de functies van regisseur en producent (en soms ook scenarist) combineerde. Ook wanneer er wel degelijk een onafhankelijk productiehuis betrokken was, bleef de regisseur vaak de spil van het filmproject. Roland Verhavert zag zijn productiehuis Visie bijvoorbeeld in de eerste plaats als een vehikel om zijn eigen regisseursprojecten en die van bevriende cineasten te faciliteren. ${ }^{24}$ Zo goed als alle belangrijke creatieve beslissingen bleven bij de regisseur berusten. Bij de Kunst en Kino-producties was dit geenszins het geval. Het creatief proces van het samenbrengen van onderwerp, regisseur, cast en crew trok Van Raemdonck doorgaans volledig naar zich toe. ${ }^{25} \mathrm{Hij}$ zocht naar de juiste personen om het eindresultaat zo dicht mogelijk te laten aansluiten bij de film die hij zelf voor ogen had. Van Raemdonck schrok er niet voor terug druk uit te oefenen wanneer de visie van het 'creatieve personeel' niet overeenstemde met die van zichzelf, wat in het geval van wiLDSCHUT zelfs tot de vervanging van de initiële regisseur leidde. ${ }^{26}$ In een interview uit I984 vatte hij zijn visie hierop als volgt samen: 'In een bedrijf laat je toch ook niet de vrije hand aan de ingenieurs? ${ }^{27}$ Roland Verhavert stelt dat dit precies een van de redenen was waarom hij na RUBENS niet meer als regisseur met Van Raemdonck wou samenwerken: 'Nadien kon ik niet meer met hem verder, hij wou te veel zijn stempel op de film zetten, qua stijl, vanuit zijn persoonlijke smaak, en een soort geldingsdrang. ${ }^{28}$ Hierbij dient opgemerkt dat Van Raemdoncks invloed bij de opnamen van de film nog relatief beperkt was in vergelijking met zijn inbreng tijdens de montagefase. Zoals hij zelf herhaaldelijk aangaf, kwam hij tussenbeide als er volgens hem een probleem rees 'met de begrijpelijkheid of de lengte [van de film]'. ${ }^{29}$ Op die manier verzekerde hij zich van het uiteindelijke beslissingsrecht over de filmtekst, voornamelijk om de publieksvriendelijkheid ervan te garanderen.

\section{Professionalisme}

Om de respectabiliteit en het kwaliteitslabel van zijn producties te garanderen, legde Van Raemdonck sterk de nadruk op het gebruik van de hoogste professionele standaarden in het 
productie- en distributieproces. In dit opzicht krijgt hij erkenning voor zijn aandeel in het professionaliseren van de Belgische en voornamelijk de Vlaamse filmindustrie. Na zijn overlijden in 2010 werd hij door Jacques Dubrulle bijvoorbeeld geroemd als 'de allereerste echte filmproducent. Jan tilde de Vlaamse filmwereld uit het amateurisme en maakte er een echte professionele sector van. ${ }^{30}$ In de kleine en onderontwikkelde Vlaamse audiovisuele productiesector gold Kunst en Kino als een garantie voor stevig voorbereide productiedossiers met een naar Vlaamse normen groot budget, een professionele filmuitrusting en voldoende cast- en crewleden op de set, die bovendien serieuze contracten kregen en correct uitbetaald werden. Van Raemdonck stond bekend als een flamboyante man die op zakelijk vlak zeer strikt en punctueel was. Toen de Nederlandse producent Gerrit Visscher voor het eerst samenwerkte met Van Raemdonck, was hij bijvoorbeeld verrast over hoe formeel alles steeds diende te gebeuren: 'Er waren geen losse overeenkomsten, alles moest op papier neergeschreven worden. ${ }^{3 \mathrm{I}}$ In lijn hiermee herinnert een voormalig staflid van de filmdienst van de Vlaamse overheid hoe het steeds een plezier was om met Van Raemdonck samen te werken: 'Ik heb hem nooit een herinnering moeten sturen, hij betaalde altijd zijn deel op tijd terug (...) Van Raemdonck toonde ook zijn contracten. Hij was de enige. ${ }^{32}$ Zijn discipline en toewijding kwamen ook tot uiting in zijn sectoraal engagement in diverse professionele associaties en commissies om de belangen van de Vlaamse en Belgische audiovisuele productie-industrie te verdedigen. Van Raemdonck wou de werkomstandigheden verbeteren en de continuitteit in de filmproductie verhogen. Verwijzend naar het gemiddelde van drie tot vijf Vlaamse films die vanaf de jaren vijftig tot de jaren negentig ieder jaar uitkwamen, stelde hij dat 'on ne construit pas une industrie cinématographique sur des exceptions'.33

Een ander belangrijk aspect van Van Raemdoncks professionalisme was zijn aandacht voor een sterke marketingstrategie. Dit ging veel verder dan het onderhouden van goede relaties met bepaalde pers-, distributie- en vertoningsactoren; vaak werden zijn producties getransformeerd tot alomtegenwoordige multimedia-events. Dit was erg uitzonderlijk voor Belgische filmproducties uit die tijd en droeg bij aan het succes van diverse van zijn films en hun plaats in de Belgische filmhistoriografie. Een goed voorbeeld van een doorgedreven marketingstrategie vinden we terug bij de film (I984) en televisieserie (I985) DE LEEUW VAN VLAANDEREN. ${ }^{34}$ In DE LEEUW staat de Guldensporenslag uit 1302 centraal, waarin de graaf van Vlaanderen de koning van Frankrijk versloeg. De productie was gebaseerd op Hendrik Consciences gelijknamige roman uit I838, een mijlpaal binnen het cultureel en mythologisch repertorium van de Vlaamse beweging. Voor Van Raemdonck gold dit werk echter in de eerste plaats als een vehikel dat mogelijkheden bood om een historische spektakelproductie op poten te zetten. Hoewel zijn pastorale films uit de jaren zeventig reeds tot de meest prestigieuze Vlaamse filmproducties behoorden, koesterde Van Raemdonck nog grotere aspiraties met DE LEEUw, en daarvoor was een gepaste promotie- en marketingcampagne nodig.

Reeds tijdens de voorbereidingen en de opnames werd er grote ruchtbaarheid gegeven aan de productie. De Minister van Cultuur Karel Poma was aanwezig op de eerste draaidag, en in de daaropvolgende maanden verschenen er, voornamelijk in de Vlaamse, maar ook in de Franstalige Belgische en de Nederlandse pers, uitgebreide artikels, interviews en setverslagen, waarbij voornamelijk gefocust werd op de ongeziene omvang van 'deze eerste Vlaamse 
superproduktie', zoals Spectator schreef. 35 Deze media-aandacht werd uiteraard sterk gestimuleerd door de producenten, met naast Van Raemdonck ook een actieve rol voor de BRT, die de honderdste sterfdag van Conscience extra luster wilde bijzetten. ${ }^{36}$ Zo werd er een boek (rijkelijk geïllustreerd met foto's uit de televisieserie) uitgegeven op basis van het scenario, en werden een setreportage en een korte documentaire over de opnames gerealiseerd. Voor de Nederlandse markt werd een documentaire gerealiseerd over het boek van Conscience en zijn betekenis voor Vlaanderen en België, om op die manier het Nederlandse publiek reeds vertrouwd te maken met het onderwerp van de aankomende film en televisieserie.

Daarnaast werden ook enkele meer gewiekste strategieën toegepast om DE LEEUW in de schijnwerpers te plaatsen. Zo ontstond tijdens de productievoorbereidingen een volgens $D e$ Standaard bewust georganiseerde heisa rond het plan van Kunst en Kino om met een Britse filmploeg te werken. ${ }^{37}$ Uiteindelijk kwam het bericht dat de ploeg bijna volledig VlaamsNederlands zou zijn, waarbij alleen de moeilijke gevechtsscènes - Vlaanderen of Nederland beschikte hiervoor amper over expertise -, door twee Britse specialisten geleid zouden worden. Ook toen de film uitkwam, bleef de promotiemachine op volle toeren draaien. Zo werden in verschillende Vlaamse treinstations grote videoreclames opgesteld met beelden van de veldslag, en verschenen in diverse kranten 'publiciteitsrecensies' die eruit zagen als een artikel of een recensie van de film, maar louter promotiemateriaal waren. Op die manier werd DE LEEUW getransformeerd tot een belangrijk en alomtegenwoordig multimediaevent. Het in verhouding tot de kostprijs en de promotie eerder geringe publieke en kritische succes van DE LEEUw toont echter tegelijk aan dat ook de marketing slechts een van de factoren vormt in het complexe proces dat leidt tot een succesvolle film. ${ }^{38}$

\section{Fondsenwerving}

Van Raemdoncks grootste professionele en strategische talent was ongetwijfeld het aantrekken van middelen voor zijn producties. Binnen de Belgische context was dit des te opmerkelijker, omdat de kleine thuismarkt het nagenoeg onmogelijk maakte voor audiovisueel product een om rendabel te zijn. Van Raemdonck hanteerde grofweg drie strategieën om deze handicap te overkomen: het inzetten op coproducties, aanboren van privaat kapitaal en waar mogelijk overheidsmiddelen gebruiken. Binnen de Vlaamse filmsector was Van Raemdonck een van de eerste producenten die op structurele basis inzette op coproducties met Nederland. Zijn terugkerende samenwerking met Gerrit Visscher culmineerde zelfs in de gemeenschappelijke onderneming TFPA, een Nederlands bedrijf dat zich voornamelijk richtte op televisieproducties. Zo goed als al zijn francofone producties ontstonden dan weer in coproductie met Franse maatschappijen. Binnen de kleine Belgische filmsector zag Van Raemdonck coproducties, net zoals samenwerkingen met televisiemaatschappijen, als een noodzaak waarvan hij gretig een deugd maakte. Met de komst van Europese coproductiestimulansen 39 in de loop van de jaren tachtig zag hij bovendien nieuwe mogelijkheden; hij was ervan overtuigd dat de toekomst van de Belgische audiovisuele productie in een geïntensifieerde Europeanisering lag. ${ }^{40}$

Voor het probleem privaat kapitaal aan te trekken was Van Raemdoncks oplossing bedrieglijk simpel: 'De privé-sektor zoekt alleen maar winst. Je moet goede zaken voorstellen, 
het geld terugbetalen en winst verzekeren: zo wek je het vertrouwen bij de financiële milieus. Tot nog toe heb ik zelf daarmee nog geen moeilijkheden gehad. Of het nu voor film is, of voor de staalnijverheid of andere takken, het komt er alleen op aan te bewijzen dat iets interessant is. ${ }^{4}$ I Alle geïnterviewden waren het er echter over eens dat Van Raemdonck bij deze onderhandelingen ook over een sterke set van tactische overtuigingsvaardigheden beschikte, waarbij hij zijn zaken regelde tijdens een informele maaltijd, wat hem voor producent Pierre Drouot de titel van 'king of lunches' opleverde. ${ }^{42}$ Het belangrijkste en wellicht zelfs enige selectiecriterium in Van Raemdoncks zoektocht naar mogelijke investeerders was hun capaciteit om financiële of logistieke steun te bieden, ongeacht hun taal-, culturele of nationaliteitsachtergrond. Binnen de Belgische communautaire context en voornamelijk de institutionaliserende Vlaamse emancipatie in die tijd, was dit niet zo evident als het misschien zou klinken. Zoals een staflid van de filmdienst van de overheid zich herinnert: 'Hij lobbyde overal, waar hij ook maar geld kon halen. Er waren er die zeiden, hij heult maar met die en die, wij blijven toch trouw aan Vlaanderen, maar Van Raemdonck ging ook bij de Franstaligen geld halen. 43

Hoewel Van Raemdonck van thuis uit op de Franstalige cultuur gericht was, getroostte hij zich grote inspanningen om vertrouwd te raken met de Vlaamse, Nederlandstalige cultuur. Gezien de communautaire gevoeligheid van de taalkwestie, sprak Van Raemdonck niet enkel vloeiend Nederlands (een Frans accent behield hij evenwel altijd), als opportunistisch gebaar gebruikte hij in zijn Nederlandstalige contacten ook steeds de voornaam 'Jan', het Vlaamse equivalent voor zijn officiële naam 'Jean'. Op dezelfde manier vertaalde hij ook 'Art et Cinéma' in 'Kunst en Kino', terwijl hij de originele Franse bedrijfsnomenclatuur voor zijn Franstalige contacten behield. Zoals ook Roland Verhavert opmerkt, waren deze keuzes in de eerste plaats zakelijk geïnspireerd: 'Er was een Vlaamse emancipatie op cultuurvlak, en hij wist dat er op dat spoor meer te rapen viel dan op dat moment bij de Franstaligen.'44

In lijn met Van Raemdoncks pragmatische instelling kunnen we opmerken dat de speelfilmproductie van Kunst en Kino begon kort na de introductie van systematische culturele filmsteun in België: aan Nederlandstalige kant was dit in 1964, aan Franstalige kant in I967. Deze overheidssteun is van essentieel belang gebleken voor het grootste deel van de Belgische filmproducties. Voor Van Raemdonck gold dit voornamelijk voor zijn Nederlandstalige lange speelfilms, die alle met een substantiële inbreng van de Vlaamse subsidieregeling tot stand kwamen. Dit mechanisme hield in dat een filmcommissie advies uitbracht over de filmprojecten waarvoor subsidie werd aangevraagd, waarop de bevoegde minister de definitieve beslissing nam. ${ }^{45}$ Aangezien deze overheidssteun de belangrijkste inbreng vormde in Kunst en Kino's filmproducties, gaan we in de volgende paragraaf dieper in op hoe Van Raemdonck er gedurende de jaren zeventig en tachtig in slaagde om de grootste overheidstoelagen binnen te halen.

\section{Overheidssteun}

Dankzij het succes van MIRA (I97I) begon Van Raemdoncks relatie met de Vlaamse subsidiegevers zeer positief. MIRA werd niet enkel geapprecieerd omwille van het populaire en kritische succes, maar ook omdat het de eerste film was die een deel van de overheidssteun 
(in feite een speciale lening die in de praktijk grotendeels of volledig als subsidie fungeerde) terugbetaalde. ${ }^{46}$ Dit vergrootte het vertrouwen in de Vlaamse films bij diverse beleidsactoren, wat zich onder andere vertaalde in de verhoging van het filmbudget in 1972 van 20 naar 24 miljoen Belgische francs. ${ }^{47}$ MIRA bezorgde Van Raemdonck ook een geprivilegieerde status bij de filmcommissie, zoals bleek uit de commissienotulen: 'de Commissie brengt hommage aan de productie van MIRA en gaat er mee akkoord dat de producent voor goedgekeurde ontwerpen prioriteit geniet. ${ }^{48}$ Het positieve advies voor Kunst en Kino's volgende film DE LOTELING was dan ook grotendeels gebaseerd op het precedent van MIRA. Toen DE LOTELING aan de commissie werd voorgesteld, bekritiseerde deze de film echter op zijn 'folkloristische karakter', wat de commissieleden ook al bij MIRA in enige mate hadden opgemerkt. ${ }^{49}$ De commissie doelde hiermee op de nostalgische en romantische beeldvoering die de Vlaamse filmadaptaties van plattelandsromans kenmerkten. Bijgevolg maakte de commissie 'het allergrootste voorbehoud wat de verfilming door Verhavert van PALLIETER betreft', Kunst en Kino's volgende op stapel staande filmproject..$^{\circ}$

Van Raemdonck anticipeerde op het negatieve commissieadvies en beloofde PALLIETER 'een expressionistische opvatting te geven, volkomen anders dus dan MIRA en DE LOTELING'.$^{\text {I }}$ Op een latere hoorzitting met de commissie herhaalde Van Raemdonck zijn bereidheid om tegemoet te komen aan de commissie die haar bezorgdheid uitsprak dat de film 'wel eens zou kunnen vervallen in pure folklore' en probeerde hij ook in te spelen op de drang van de commissie trouw te blijven aan het literaire werk door te argumenteren dat het boek via de film in zijn oorspronkelijke gestalte hersteld [zal] worden'.52 In zijn poging om het negatieve advies om te zetten in een positief advies, speelde Van Raemdonck al zijn overtuigingskracht uit. Zo beloofde hij bij toekenning van de steun 'tegelijk met PALLIETER de distributie en de verkoop te verzekeren van twee of drie films van jonge kineasten en dit als ware het eigen produkties'.53 Volgens Verhavert lobbyde Van Raemdonck bovendien bij minister van Cultuur Jos Chabert, die vervolgens op bepaalde commissieleden druk zou hebben uitgeoefend om een positief steunadvies te geven. ${ }^{54}$

Naast de doorgedreven officiële contacten met de beleidsactoren - hij nodigde die ook steevast uit voor setbezoeken en premières -, lobbyde Van Raemdonck volgens de geïnterviewden ook altijd zeer actief op een officieuze manier, zowel bij de individuele commissieleden als bij diverse politieke actoren. Volgens Verhavert schrok hij er niet voor terug om druk uit te oefenen: 'Hij zei, ik ga naar de minister, en dan was hij ook bij de minister. ${ }^{55}$ Hoe het ook zij, het staat vast dat in april 1974 een meerderheid van de commissieleden zich bereid toonde om in het voordeel van PALLIETER te stemmen. We dienen er hier ook rekening mee te houden dat de filmcommissie eveneens oog had voor het mogelijke publieksbereik van de producties van Kunst en Kino. Na visie van de afgewerkte film was de commissie echter unaniem ontgoocheld over PALLIETER, die volgens haar, ondanks de beloftes van Van Raemdonck, 'als een uitstalling van voorbijgestreefde folklore' gold. ${ }^{6}$

Het valt dan ook niet te verwonderen dat Van Raemdonck in de hierop volgende jaren geen nieuwe pastorale filmprojecten meer aanhangig makte bij de filmcommissie. Wel engageerde hij zich voor de televisieserie RUBENS (I977), de Nederlandse coproductie DOKTER VLIMMEN 
(I978) en Claus' theateradaptatie VRIJDAG (I980), projecten die alle een veel vlotter toelatingsproces kenden. Toen aan het einde van de jaren zeventig de samenstelling van de filmcommissie vernieuwd werd, waagde Van Raemdonck opnieuw zijn kans met een pastoraal filmproject, DE VLASCHAARD (I983).

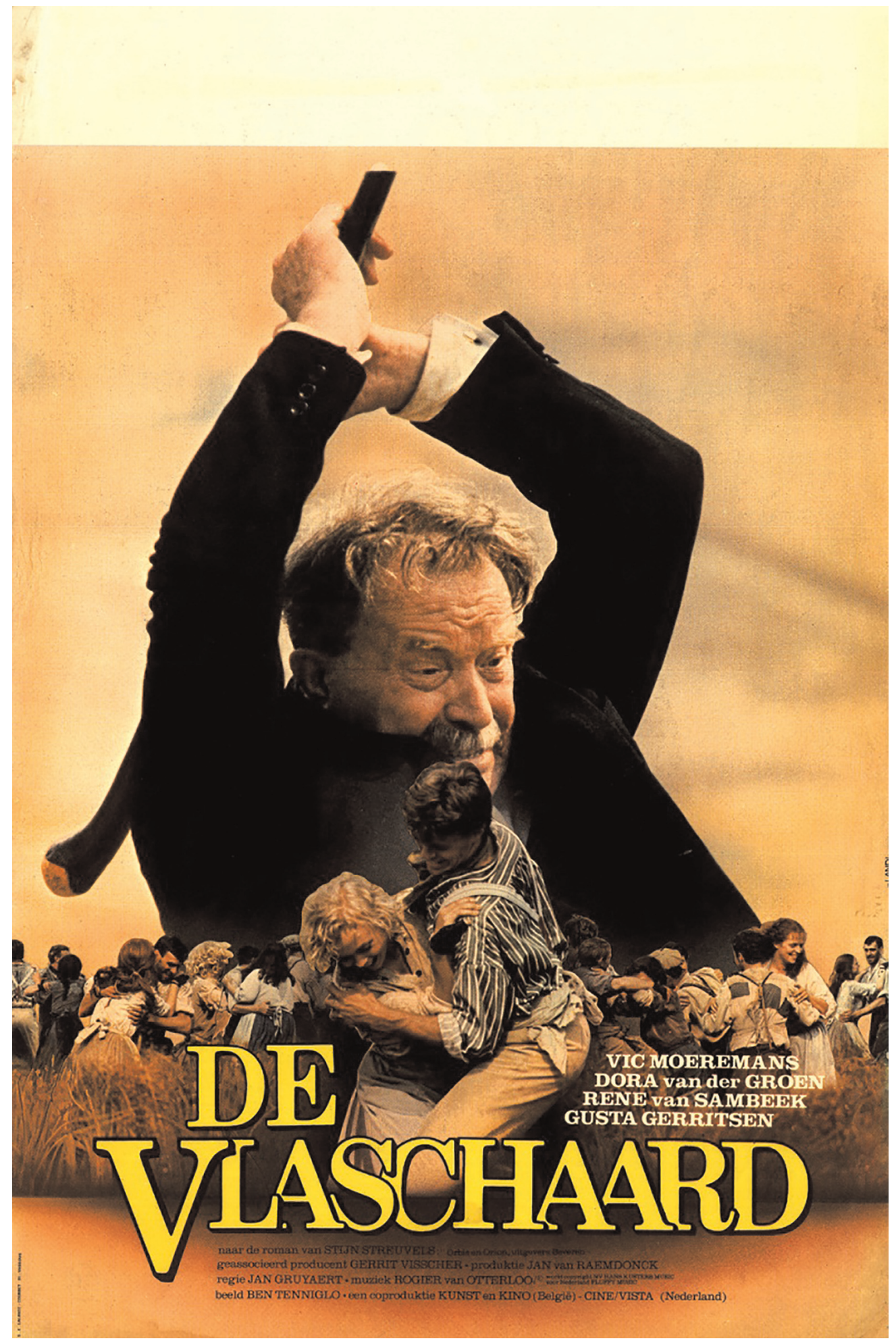

Afb. 3 Filmaffiche DE VLASCHAARD

Bron: Koninklijk Belgisch Filmarchief 
Hoewel de nieuwe commissieleden net als hun voorgangers bezorgd waren over het mogelijk folkloristische en romantische karakter van pastorale films, slaagde Van Raemdonck er opnieuw in de commissie te overtuigen. Ditmaal speelde hij de artistieke verdiensten van de regisseur Jan Gruyaert uit, die net de onconventionele film IN KLUIS (I978) had gerealiseerd. De commissie adviseerde positief over het project 'op voorwaarde dat een maximale artistieke vrijheid kan verleend worden aan de realisator, ten einde de verwezenlijking van een traditionele heimatfilm te vermijden. ${ }^{57}$ Net als bij DE LOTELING en PALLIETER was de commissie opnieuw ontgoocheld over het eindresultaat, en oordeelde zij dat DE VLASSCHAARD behoorde 'tot het pakket van de traditionele Vlaamse heimatfilms'. ${ }^{8}$

Een gelijkaardige gang van zaken vinden we terug bij de Nederlandse coproductie WILDSCHUT (1985). De commissie gaf aanvankelijk een negatief advies, omdat zij de actiefilm, met de nodige portie naakt, 'louter commercieel opgevat' vond. ${ }^{59}$ De producenten kregen toch een positief advies na diverse garanties 'betreffende de thematische en stilistische uitwerking van de intrige'. ${ }^{60}$ Toen de commissie de afgewerkte film zag, vond dat zij om de tuin was geleid: 'De commissie heeft in de beelden van deze film al de bezwaren gezien die ze op basis van het oorspronkelijk scenario had geformuleerd. Ze stelt vast dat de herwerking, door de drie producenten tijdens een hearing toegezegd en die enige diepgang had kunnen brengen in dit gangster-verhaal, na de uitbrenging van een gunstig advies terzijde werd gelegd. ${ }^{61}$

\section{Besluit}

$\mathrm{Na}$ het produceren van talloze kunstdocumentaires legde Van Raemdonck (I922-20I0) zich aan het einde van de jaren zestig toe op de productie van fictieproducties. Hoewel hier incidenteel televisieproducties bij waren, gold Van Raemdonck met zijn productiemaatschappij Kunst en Kino gedurende de jaren zeventig en tachtig in de eerste plaats als een van de belangrijkste lange speelfilmproducenten in België, voornamelijk in Vlaanderen. Van Raemdonck streefde steeds naar stevige productiedossiers, zo hoog mogelijke filmtechnische standaarden, serieuze contracten met cast en crew, getroostte zich grote promotie- en marketinginspanningen, ging structurele partnerschappen met buitenlandse producenten aan en benutte publieke en private middelen maximaal. Ook toonde hij een sterk sectoraal engagement via diverse professionele associaties en commissies. Op die manier leverde hij een belangrijke bijdrage aan de professionalisering van de Belgische audiovisuele industrie, voornamelijk van de Vlaamse filmsector. Van Raemdoncks bijdrage kan echter niet geïsoleerd gezien worden. Vanaf de jaren zestig professionaliseerde de audiovisuele productiesector in Europa zich immers, onder andere gestimuleerd door een groeiende televisieproductie, overheidssteunmaatregelen en de opkomst van filmscholen en filmfestivals. Binnen deze context was Van Raemdonck een van de sleutelactoren in Vlaanderen.

Binnen Van Raemdoncks lange loopbaan was hij coproducent van twee Nederlandse producties en hoofdproducent van twee Franstalige en zeven Nederlandstalige Belgische lange speelfilms. In vergelijking met sommige buitenlandse voorbeelden kan dit een beperkte output lijken, maar binnen een Vlaamse context waarin gemiddeld vier lange speelfilms per jaar verschenen, leverde Van Raemdonck een belangrijke bijdrage aan de continuïteit binnen de Vlaamse filmproductie, vooral dankzij zijn zakelijk talent. Kunst en Kino's prominente 
productie-output van lange speelfilms in de jaren zeventig en tachtig golden als meest prestigieuze en populaire producties en kregen de grootste subsidiebedragen toebedeeld. Het folkloristische en nostalgische karakter van historische pastorale films gebaseerd op Vlaamse literaire klassiekers werd echter bekritiseerd door de Vlaamse filmcommissie. Deze films werden tot nog toe meestal benaderd vanuit een regisseursperspectief, maar Van Raemdoncks rol als drijvende kracht, in combinatie met zijn sterke betrokkenheid en controledrang, wijst op de complexiteit van de vraag naar de creatieve autoriteit. We kunnen niet genoeg benadrukken dat ook voor de producent geldt, net als voor de regisseur, dat deze slechts één schakel vormt binnen het complex van (zowel individuele als institutionele) krachten die het uiteindelijke filmproduct mee vormgeven.

\section{Noten}

Gebruikte afkortingen in de noten die verwijzen naar het expliciete gebruik van archiefmateriaal van het filmdepartement van de Vlaamse overheid (ondergebracht in het Rijksarchief te Beveren) zijn: RAB (Rijksarchief Beveren), AMF (Archief Media en Film), CV (Commissievergadering) DAVRT (Documentenarchief Vlaamse Radio en Televisie) en DSI (Dossiers du Secrétariat de l'Institut).

I. Over het gebrek aan professionele producenten in de Belgische filmindustrie, zie: F. Bolen, 'De quelques producteurs, des vrais', in: Ciné-Dossiers, vol. 62, I977, p. I-8; Ph. Mosley, Split screen: Belgian cinema and cultural identity, State University of New York Press, New York 200I, p. I05.

2. Voor een goed voorbeeld van een studie waarin zowel stilistische als productionele elementen benadrukt worden, zie D. Bordwell, J. Staiger \& K. Thompson, The classical Hollywood cinema: film style and mode of production to 1960, Routledge, London 1985.

3. Zie bijvoorbeeld A. Spicer, 'The production line: reflections on the role of the film producer in British cinema', in: Journal of British Cinema and Television, I, vol. I, 2004, p. 33-35. Ook in diverse inleidende filmhandboeken wordt dit steeds meer benadrukt, zie bijvoorbeeld J. Nelmes, Introduction to film studies, Routledge, London 1996; D. Bordwell \& K. Thompson, Film art: an introduction, McGraw-Hill, New York 2013 (10 ${ }^{\text {de }}$ editie).

4. Dit zijn René Adams (voorzitter van de Vlaamse filmcommissie, I983-1989), Pierre Drouot (producent), Harry Kümel (regisseur, onder andere voor de Kunst en Kino-productie the SECRETS of LOVE), Bert Podevyn (overheidsadministratie dienst film), Karel Poma (Vlaams minister van Cultuur, I98I-I985), Frans Puttemans (lid van de filmcommissie, I983-I986 en I993-I999), Roland Verhavert (producent en regisseur, onder andere voor de Kunst en Kinoproducties De LOTELING, PALLIeTER en RUbens) en Gerrit Visscher (Nederlands producent die als Van Raemdoncks vaste Nederlandse coproductiepartner fungeerde, onder andere voor PALLIETER, DE VLASCHAARD, WILDSCHUT, DOKTER VLIMMEN, VRIJDAG En THE SECRETS OF LOVE).

5. K. Van der Auwera, 'Wonen in Brussel: Jan Van Raemdonck, filmproducent', Brussel Deze Week, 5 oktober 2006.

6. F. Bolen, 'Un Producteur: Jean Van Raemdonck', Ciné-Dossiers, 70, 1978, p. II. Luc Haesaerts, de broer van Paul Haesaerts, was een van de stichtende leden van Cinéma Inter-Entreprises. Andere bestuursleden waren hertog Henri d'Ursel en François Vandenborre, de voorzitter was minister Piet Vermeylen.

7. Zie S. Jacobs, Framing pictures: film and the visual arts, Edinburgh Studies in Film, Edinburgh 20II, p. I5-I7.

8. Bolen, 'De quelques producteurs', p. 2.

9. Behalve Haesaerts en Storck zijn ook Charles Dekeukeleire, André Cauvin en Luc de Heusch vaak geciteerde regisseurs binnen deze traditie. Zie M. Barsam, Nonfiction film: a critical history, Indiana University Press, Bloomington I992, p. 258; S. Jacobs, Art \& cinema: Belgian art documentaries, Cinematek, Brussel, 2013.

IO. LES GALAPIATS bestond uit 8 episodes van 26 minuten en werd onder andere gedistribueerd naar de Belgische, Nederlandse, Franse, Canadese, Zwitserse, Italiaanse, Portugese en Luxemburgse televisie.

II. MON VOISIN DU DEssus kreeg in 2007 een Amerikaanse remake als THE NEIGHBOR (Eddie O'Flaherty), zie D. Brahimi, Les teléfilms Français:nos contes initiatiques, Harmattan, Parijs 20II, p. 90-9I. 
I2. E. Martens, 'Mira', in: E. Mathijs (red.), The cinema of the Low Countries, Wallflower Press, London 2004, p. 89. Het was Hugo Claus die de keuze van het boek bepaald had.

I3. M. Janssens, 'De verfilming van De teleurgang van de waterhoek', in: P. Thomas (red.), De huid van Mira, Lannoo, Tielt I998, 74 .

I4. Het begrip 'MIRA formule' wordt ontleend aan Martens, 'Mira', p. 88.

I5. Het budget voor MIRA was I7 miljoen BEF, voor DE LOTELING I4 miljoen BEF, voor PALLIETER I6 miljoen BEF, voor DE VLASCHAARD 23,9 miljoen BEF, voor DE LEEUW VAN VLAANDEREN 80 miljoen BEF en voor HET GEZIN VAN PAEMEL 40 miljoen BEF. In vergelijking met andere Vlaamse producties uit die tijd waren dit steeds hoge tot zeer hoge budgetten.

I6. Zie bijvoorbeeld Mosley, Split screen, p. II4; J.-P. Everaerts, Film in België: Een permanente revolte. Mediadoc, Brussel 2000, p. 245; G. Willems, 'Film policy, national identity and period adaptations in Flanders during the I970s and I980s', in: Historical Journal of Film, Radio and Television, april $20 \mathrm{I4}$ (online first), p. I-3.

I7. E. Brems, 'The genealogical novel as a way of defining and/or deconstructing cultural identity: Flemish fiction since I970', Memory Studies, I vol. 5, 2012, p. 78-79.

I8. Roland Verhavert, interview met de auteur, Torhout, 5 februari 2013.

I9. Gerrit Visscher spreekt in dit verband over een 'leerknechtverhouding'.

20. Het feit dat Van Raemdonck sterke interesse had in de concrete tekstuele opzet van films bleek ook uit de realisatie van de erotische kortfilm LES BIJOUx (I986). Gebaseerd op het gelijknamige gedicht uit Charles Baudelaires dichtbundel Les fleurs du mAL (1857) was LES BIjOux Van Raemdoncks eigen (en enige) regisseursavontuur.

2I. Mosley, Split screen, p. I73.

22. G. Visscher, interview met de auteur, Huizen, 25 maart 2013.

23. F. Sojcher, La kermesse héroïque du cinéma belge: Le miroir déformant des identités culturelles (1965-1988), l'Harmattan, Paris I999, p. 297

24. R. Verhavert, interview met de auteur, Torhout, 5 februari 20I3. Na Kunst en Kino was Visie een van de meest actieve productiehuizen in Vlaanderen in de jaren 1970 en 1980.

25. De oorspronkelijke aanzet voor films als MIRA en DE LOTELING kwam wel van televisie, maar ook hier bleek Van Raemdonck een sleutelfiguur in het verdere productieverloop.

26. G. Visscher, interview met de auteur, Huizen, 25 maart 2013.

27. M. Mandy, 'Leeuw van Vlaanderen', Le Journal du Festival Blad, ig januari ig84, p. 54.

28. R. Verhavert, interview met de auteur, Torhout, 5 februari 2013.

29. Mandy, 'Leeuw', p. 54 .

30. E. De Troyer, 'Jan veranderde Vlaamse filmwereld', in: Het Laatste Nieuws, 9 november 20Io, p. I9. Zie ook F. Sartor, 'Vlaams filmproducent Jan Van Raemdonck', Filmmagie, 61о, 20Iо, p. 22.

3I. G. Visscher, interview met de auteur, Huizen, 25 maart 2013.

32. B. Podevyn, interview met de auteur, Gent, 4 februari 2013.

33. 'Une production belge d'ensemble de plus en plus qualitative', in: Moniteur du Film en Belgique - Filmwijzer in België, I00, I991, p. I7.

34. Voor een uitgebreide bespreking van de productie, tekst en receptie van DE LEEUW VAN VLAANDEREN, zie G. Willems, “'DE LEEUW VAN VLAANDEREN wil ik zo gauw mogelijk vergeten.” Over de productie en receptie van de film en televisieserie De LeEUW VAN VlaAnderen (I984)', in: Belgisch Tijdschrift voor Nieuwste Geschiedenis, 2-3, vol. 43, 2013, p. I78-209.

35. S. Vancaeneghem, 'DE LeEUW VAn VlaAnderen. Sapristi!,' in: Spectator, i6 juli ig83, p. 5 .

36. DAVRT, DSI 5803 (335), Memorandum van Paul Vandenbussche aan de Permanente Commissie, I6 maart I982; RAB, AMF, nrs. 249-253, Verslag van de Commissie van Toezicht, 20 mei i983.

37. H. Dejonghe, 'LEEUw dan toch door Vlaams-Nederlandse ploeg verfilmd', in: De Standaard, 4 juni I982.

38. In België behaalde DE LEEUW I50.000 bioscoopbezoekers, wat voor een Vlaamse film gewoonlijk als een vrij sterk resultaat werd en wordt gezien. Voor een dure prestigeproductie als DE LEEUw bleef dit bezoekersaantal echter ver onder de verwachtingen. Op kritisch vlak werd de film zo goed als unaniem neergesabeld.

39. V. Henning \& A. Alpar, 'Public aid mechanisms in feature film production: The EU media plus programme', Media, Culture \& Society, 2, vol. 27, 2005, p. 232-34.

40. 'Une production belge', p. I5-I7.

4I. J.-P. Wauters, 'Jan Van Raemdonck: Alles loopt gesmeerd...', Film en Televisie, 209, I974, p. I8.

42. P. Drouot, interview met de auteur, Gent, 28 augustus 2013.

43. B. Podevijn, interview met de auteur, Gent, 4 februari 2013 
44. R. Verhavert, interview met de auteur, Torhout, 5 februari 2013.

45. Behalve de uiteindelijke ministeriële beslissingen werden ook de commissieadviezen bekendgemaakt aan de aanvragers. Het voorliggende onderzoek deed ook beroep op de voorbereidende nota's van de filmcommissie, die niet toegankelijk waren voor de aanvragers. De filmcommissie heette officieel de Selectiecommissie voor Culturele Films, en vanaf I994 de Vlaamse Audiovisuele Selectiecommissie. De bevoegde minister voor de filmsteun was de minister van Cultuur, behalve tussen I992 en 200I, toen dit de minister van Media was. Vanaf 2002 veranderde het filmproductiebeleid door de inwerkingtreding van het autonome Vlaams Audiovisueel Fonds.

46. Kunst en Kino betaalde I,7 miljoen BEF van de 4 miljoen BEF overheidssteun voor MIRA terug.

47. Zie RAB, AMF, CV 6 mei I97I.Met deze budgetverhoging gaf minister van Cultuur Frans van Mechelen gevolg aan de oproep van de filmcommissie die naar aanleiding van MIRA te kennen gaf dat 'de film in ons land in een dergelijk evolutiestadium is gekomen dat een herziening nodig is van het budget'.

48. RAB, AMF, CV 6 mei I97I

49. RAB, AMF, CV 2I december I973.

50. RAB, AMF, CV 2I december I973.

5I. RAB, AMF, nr. I75, brief van Van Raemdonck aan de filmcommissie, 2I januari I974.

52. RAB, AMF, CV 5 april I974.

53. RAB, AMF, nr. I75, brief van Van Raemdonck aan de filmcommissie, 2I januari I974.

54. R. Verhavert, interview met de auteur, Torhout, 5 februari 2013.

55. R. Verhavert, interview met de auteur, Torhout, 5 februari 2013. Kümel (interview met de auteur, Antwerpen, 9 september 2013) typeert Van Raemdonck in dit verband als iemand die 'de ministeries platliep'.

56. RAB, AMF, CV I8 november I975.

57. RAB, AMF, CV 20 november I98I.

58. RAB, AMF, CV I3 januari I983.

59. RAB, AMF, CV II mei I984.

6o. RAB, AMF, CV I juni I984.

6I. RAB, AMF, CV 27 februari I985. 
68 Tijdschrift voor Mediageschiedenis - I8 [I] 20 I5 